\title{
プロフェッショナリズムの本質：利他主義と 社会契約を理解する
}

\section{野村 英樹}

〔日内会誌 $100 ： 1110 \sim 1120,2011$ ]

Key words プロフェッショナリズム, 利他主義, 社会契約

\section{1.はじめに}

2010 年の本誌で筆者は,「プロフェッションに よる教育と自律のあり方」と題する論文豆の中で, プロフェッショナリズムとは何か, について論 じたそそこでは, プロフェッション, 利他的な 奉仕(利他主義)，抢上び社会契約が, プロフェッ ショナリズムの基盤, あるいは本質上, 重要な キーワードであった.

これらは聞きなれた言葉のようでもあり，馴 染みのない言葉のようでもある。例えば, 利他 という言葉を耳にした時, 我々日本人は, 自己 犠牲という言葉を連想してしまわないだろうか. 「利他」という言葉自体は仏教用語であり, 本来, 悟りを開いた釈迦が, 梵天という神の要請を受 容れ (梵天衔請) て, 皆の利益のために自分の 悟りの経験を説き示す活動を行ったことを意味 していたそうである. しかし，その後仏教が変 質し, 超越的な力を持った絶対者による救済を 求める大乗仏教となって日本に伝わると, 利他 とは「自己を犠牲にして他者を救抢うとする仏
の思い」であるということになった，すなわち， 大乗仏教的な利他には, 確かに自己犠牲という 意味が含まれることになる2).

また，英語に扔ける“altruism”は，“egoism” (利己主義) の対義語として,「人間教」を創始 した 19 世紀の社会学者オーギュスト・コントが 創作した造語である。ただし、コントの思想は 西洋においても必ずしも浸透したわけではなく， “altruism”も新約聖書に扔ける「隣人愛」の上 うな意味として，その後用いられるようになっ たようである゙

このように, 洋の東西を問わず,「利他」には 宗教的な意味合いが込められていた。 しかし， 宗教とは一線を画すことになった現代のプロ フェッションに，そのまま宗教的な「利他」を 持ちこむことは無理があろう。

一方,「社会契約」という概念は, リヴァイア サンを著して絶対君主制を擁護したホッブズを 端緒としながら，米国建国の思想を築いたジョ ン・ロックにより発展し, さらに, その著書が 打上そ 120 年前に中江兆民により部分的に漢語 訳されて（民約論）我が国の民主化に影響を与

金沢大学附属病院総合診療部・総合診療内科

Series: For Attending Physicians; Professionalism; The True Nature of Professionalism : Understanding altruism and social contract.

Hideki Nomura : The Department of General Medicine, Kanazawa University Hospital, Japan. 
えたジャン＝ジャック・ルソーへと受け継がれ た現代思想である。絶対君主制を支えていた啓 蒙思想を否定し, 国家は本来, 諸個人が相互の 権利を保護するために契約を結ぶことによって 成立したものだとする思想であるが，高校の世 界史では民主主義の基盤となる合理的な政治理 論として教えられた記憶がある。その際，契約 という言葉が持つ冷たい印象が改まることはな く，また，政治理論である『社会契約論』がプ ロフェッショナリズムの基盤であると聞くと， 違和感を感じるのも事実である.

そこで本稿では, 「利他」について改めて進化 論や社会学の視点も容れて科学的に考察し, そ の延長線上で「社会契約」の概念についても本 質的に見つめ直し，我々の日常における意義を 明らかにしたいと思う。そのことを通じて，情 報の透明化, 説明責任などの一般大衆の意識の 進化の中で, 個々のプロフェッショナルとして, あるいはプロフェッションとして，プロフェッ ショナリズムのこれらの重要なキーワードをど うとらえればしっくりするか, 腑に落ちるかに ついてのヒントを提供できればと願っている.

\section{2. 利他行動の「進化」}

ダーウィンが提唱した進化論は, 神に選ばれ た存在とされてきた人間の位置付けを大きく摇 るがせたが, ダーウィンもヒトの特性の全てを 進化論的に明確に説明できたわけではなかった。 特にダーウィンを悩ませたのは，ヒトに見られ る利他行動だったようである. なぜなら, 利他 行動を

自らの適応度（生存し，自分の遺伝子を残す度合い） 上の損失を被りながら，他者に適応度上の利益をもた 与す行動

と定義した場合，このような利他行動をとるよ う変異した個体は, 自らの子孫を残すことがで きる確率が低いため, 自然淘汰の原則により利
他行動は進化し得ないはずだからである。その 後長い年月をかけて, 動物の利他行動の進化の 過程が次第に解明され ${ }^{4,5)}$, 近年ではついに, そ の延長線上でヒトの利他行動が説明されるよう になってきた.

\section{a. 直接的互恵}

血縁度が高い別の個体に対して利他行動を取 る「血縁選択」を別として, 血縁度が 0 の個体 に対する利他行動は，まず 1 対 1 の協力関係か ら始まったと考えられる。例えばチスイコウモ リは，腹いっぱい血を吸って巣に帰って来た個 体が血を吐き出し，血を吸えずに帰って来た個 体に対して血を分け与えると報告されている. このような行動は限られた個体のグループ内で のみ生じているため, 別の夜に立場が逆転し, 以前に血を与えた個体が空腹で巣に戻り, 以前 は血を与えてもらった個体が満腹で戻った時, 後者は以前のお返しに血を吐き戻して前者に与 えていると推測されるという ${ }^{6}$.

このような 1 対 1 の協力関係が(個体間の)直 接的互恵であるが, 最初に恩恵を受けた個体は, 立場が逆になった夜に，必ずしもお返しをする とは限らない。このような “利己的な”個体は “利他的な”個体と比較して適応度が高いため, その動物の群れはいずれ, 全て利己的な個体で 占められるようになるはずである。しかし実際 には，群れが利己的な個体ばかりになることは ない. その理由として，

(1)利他的な個体は，お返しをしてくれなかっ た利己的な個体を記憶することができるため, 次からはこのような利己的な個体に血を分け与 えることを控えるようになり，主として利他的 な個体間で長期的な直接的互恵関係が維持され る. そうなると利己的な個体の適応度は, 利他 的な個体よりも高くはなくなる（むしろ低いか も知れない)

(2)利已的な個体ばかりの群れは, 利他的な個 体が多くを占める群れに比べて, 群れ全体とし 
ての適応度は逆に低くなる（群選択） などが考えられている。

\section{b. 間接的互恵}

では, 血縁度 0 の個体に対する, 直接の見返 りを期待しない利他的な行動は「進化」し得る のであろうか. 自然淘汰を生き抜いてこのよう な利他行動が進化するためには, 利他行動に伴 うコストが何らかの方法で別の第 3 者の個体か ら報われなければならない。このような互恵性 のあり方を間接的互恵と呼ぶが, 例えば

(1)利他行動を第 3 者が直接観察し, その第 3 者から利他的な利益の供与を受ける

ことが考えられる．実際にある種の魚類などで 観察されているそうであるが, この場合第 3 者 の個体には利益がないので，このようなケース は稀にしか起こらない.しかし，

(2)利他行動によって良い評判が生まれ，その 評判を知った第 3 者からの利他的な利益の供与 を受ける

ならば，多くの第 3 者から利益が得られる可能 性がある。ただし，そのためには評判が言語な どの複雑なコミュニケーションによって伝えら れる必要があるため, このような現象はほとん どヒトでしか観察されない.

以上のような利他行動に関する進化論的な研 究の発展を考えた時, 利他的な個体の適応度を 犠牲にする額面通りの利他行動は存在せず, 最 初に述べた利他行動の定義に修正が必要なこと は明らかであろう。すなわち, 進化論的な視点 で利他行動とは,

自らの適応度（生存し，自分の遺伝子を残す度合い） 上の利益も得ながら, 他者に適応度上の利益をもたら す行動

であり, 協力行動, あるいは好社会性行動と呼 び換えても良いものである7).

なお最近では, 利他行動に関する研究がさら に進み，利己的な個体に対して（コストをかけ てでも）罰を与え, 利他行動を半ば強制する場
合があることや，逆に，利他的な個体に対する 罰の存在なども指摘されている8).

\section{3. 個人の発達における利他行動進化の再 現}

個体の発生〜発達においては, 進化の過程が 「再現」されることが良く知られているが, 利他 行動の進化の過程も, 個人の発達の過程で再現 されるのだろうか. この観点で興味深いのが, 倫理的ジレンマを含んだシナリオに対する回答 とその理由を, 個人の成長に沿って追跡するこ とにより確立された,「道徳性の発達段階理論 (コールバーグ) 」9)である.

\section{【ハインツのジレンマ】}

ヨーロッパで,一人の婦人がたいへん重い病 気のために死にかけていた。その病気は特殊な がんだった，彼女が助かるかもしれないと医者 が考えるある薬があった。 それは，おなじ町の 薬屋が最近発見したラジウムの一種だった。そ の薬の製造費は高かったが, 薬屋はその薬を製 造するのに要した費用の 10 倍の值段とつけてい た. 彼はラジウムに 200 ドル払い, わずか一服 分の薬に 2,000 ドルの值段をつけたのである. 病 気の婦人の夫であるハインツは，あらゆる知人 にお金を借りに行った. しかし, 薬の值の半分 の 1,000 ドルしかお金を集めることができなかっ た.彼は薬屋に妻が死にかけていることを話し， 薬をもっと安くしてくれるか, でなければ後払 いにしてくれるよう頼んだ。だが薬屋は「だめ だ，私がその薬を発見したんだし，それで金儲 けをするつもりだからね.」と言った。 ハインッ は思いつめ, 妻のために薬を盗みに薬局に押し 入った。 
コールバーグは参加者に対してこのシナリオを 提示し，ハインツはどうすべきか（薬を盗むべ きか, 盗まざるべきか), その理由は何かを尋ね, その参加者が成長する過程で, 答えとその理由 がどのように変化して行くかを分析したそその 結果コールバーグは, シナリオに対してどのよ うな回答をしたとしても，その理由づけについ て全ての人は，同じ 6 つの段階を同じ順序で上 昇しながら成長して行くことを「発見」した.

【前慣習的レベル】

第一段階：罰と服従志向

自分が権威（親や教師など）から罰せられな いこと自体に価值がある（権威の尊重はない）

例：(ハインツは薬を盗むべきだ,と答えた場 合の理由づけ，以下同じ）捕まらないように夜 中に盗めば良いのです

第二段階：道具主義的相対主義者志向

自分自身の必要を満たすことが役立つ行為で あり，自分自身の必要を満たすためであれば, 交換で他者の必要を満たすことも良い行為であ る

例：彼は刑務所に行くことになるかも知れま せんが，それでも彼は奥さんを必要としている のですから

【慣習的レベル】

第三段階：対人関係の調和あるいは「良い子」志 向

人が喜び，人から承認される行動が良い行動

例：奥さんのために薬を盗んだハインツの行 動は，褒められこそすれ，責められるものでは ないと思います

第四段階：「法と秩序」志向

権威, 定められた規則, 社会秩序の維持等へ の志向

例：結婚とは，相手を一生大事にすると社会 に約束することですから，ハインツが妻を助け
るのは一種の義務だと思います

【脱慣習的レベル】

第五段階：社会契約的遵法主義志向

正しい行為は，一般的な個人の権利や，社会 全体により批判的吟味され，合意された基準に よって規定される

例：人命が危機に瀕していたのだから，ハイ ンツには正当な理由があったと思います。それ は薬屋の権利に優先されるべきものです 第六段階：普遍的な倫理的原理志向

正しさは, 論理的包括性, 普遍性, 一貫性に 訴えて自ら選択した倫理的原理に一致する良心 の決定によって規定される

例：人命尊重の義務と社会的規則に従う義務 の暮藤を解決するため, 最も弱い者の立場で考 えて，どちらの義務が優先されるべきか，とこ とん話し合うべきです

コールバークの研究は当初対象者が男性に限 られていたため, 女性の道徳性の発達は異なる のだという批判などにも晒されたが，その後多 くの研究者による検討により, 女性でも同じ段 階を経て成長することや，この発達段階は国や 民族を超えて普遍的に観察されることが明らか となっている10).

最初のステップである第一段階は，自分に対 して罰を下す権威に対する服従の段階であるが, 次の第二段階は注目に值する。他の個体と直接 に利益のやり取りをすることを始めたこの段階 は，まさしく「直接的互恵」関係の誕生である. この場合，利益をやり取りする相手は，自分が 利益を得るための「道具」ないし「手段」であ る(道具主義).

そして次の第三段階では, 周囲の「評判」を 気にし始めており，「間接的互恵」の意識が芽生 えている．第二段階と第三段階の間のステップ は大きく，第三段階は次の第四段階と共に「慣 
習的レベル」と呼ばれている，第四段階は，自 分の行動を規定する「評判」を, 社会の秩序や 規則にまで拡げた段階と言えるだろう。北米で の調査では, 医学部学生の多くは第三段階と第 四段階の中間付近にあったと報告されている11,12).

次の第五段階では, 自分の行動を規定するも のを,「評判」や既定の「ルール」のような他者 によるものではなく, 基本的人権のようなより 根源的なものに求めるようになる。第五段階へ のステップも大きなステップであり,コールバー グは第五段階以上を「脱慣習的レベル」として 区別している，言い換えれば，法律は無条件に 正しいわけではなく，その法律を作るのは，基 本的人権のような万人が持つ不可侵の権利を互 いに尊重することを前提とした, 社会全体の熟 議に基づく互恵的なルールの合意によるという 考え方である.ここで,「互酬性」のあるやり取 りを「合意」することは「契約」の定義 ${ }^{13)} に$ 沿っ ており,このような合意は「社会契約」と呼ば れる.さらに上の第六段階は，何を正義とする かを決定する上で，何らかの倫理的原理に従う 段階である，例えばそれは, 功利主義でも, リ ベラリズムでも，コミュニタリアニズムでも良 いが，自分の欲求を満たすために都合よくこれ らの倫理的原理を利用することではないのは当 然である。

このように, 個人における道徳性の発達とい う視点に立つと, ヒトの成長過程において, 最 初は直接的互恵から間接的互恵への利他行動の 進化の過程が再現されることがわかる. しかし その後, ヒトでしか見られない脱慣習的レベル (社会契約〜倫理的原理志向)に到達する個体が 存在する点で, ヒトは進化上極めてユニークな 存在なのだろう.

さて, 個人における道徳性の発達は, 国や民 族を超えて共通していることは先に述べたが, しかし各国の社会状況によって, 特に第五段階 以上にまで発達する個体の割合は大きく異なる

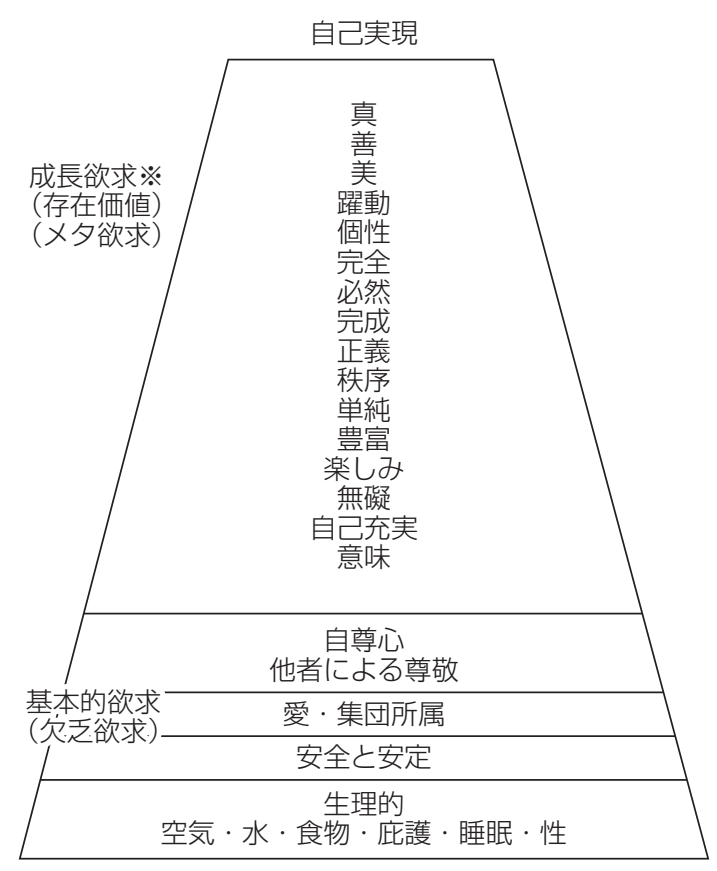

※成長欲求はすべて同等の重要さを持つ （階層的ではない）

図 1. アブラハム・マズロー : 欲求の階層

ことが知られている。一旦上がった段階が半段 階以上大きく低下した例は観察されないそうで あるが，ここでいう「観察」は，仮想のジレン マシナリオに対する回答と道徳的理由づけを対 象としていることに留意が必要である.すなわ ち, シナリオに対する回答と理由づけでは上の 段階に進んだ個人でも, 自分自身が置かれた状 況によっては, 下の段階の道徳的行動をとり得 るのである. そのことを考える上では, マズロー による欲求の階層の概念が有用と思われる.

\section{4. 欲求の階層}

マズロー14)は, 人間の欲求には階層があるとし た (図 1 参考文献 15 より引用). すなわち, 低 いレベルから

1. 生理的欲求

2. 安全の欲求 
3. 愛と所属の欲求

4. 承認の欲求

5. 自己実現の欲求

である.このうち, 最初の 4 層は基本的欲求と して階層的（より下層の欲求が欠乏すると, 上 層の欲求は後回しになる）であり, 久乏すると その欲求を自覚するが, 満たされていると自覚 はされないことがほとんどである(欠乏欲求).

一方, 第 5 層の自己実現の欲求は成長欲求と呼 ばれ, 通常, 愛と所属の欲求, および承認の欲 求がある程度満たされて初めて発生することを マズローは見出している，第 5 層の上には，さ らに自己超越の欲求の段階があるという.

ここで, 利他行動の進化という観点から注目 したいのは, 通常承認の欲求と訳されている第 4 の階層である. 英語ではesteemであるので, 尊 重の欲求と訳しても良いかも知れない.コール バーグの道徳性の発達段階では, 周囲からの良 い評判を得ることを善とするのが第三段階, そ れが発展して社会のルールや秩序に従うことを 善とするのが第四段階であった。このような行 動は, マズローが言うところの尊重の欲求によっ て動機づけられているのであろう。

マズローによれば，承認の欲求はさらに次の 二つに分けられる.

(1)強さ, 達成, 適切さ, 熟達と実践的能力, 自信, 独立と自由などに対する欲求

(2)（他者からの尊敬や尊重と定義される）評 判や威信, 地位, 名声と栄光, 優越, 承認, 注 目, 重視, 威信, 好評などに対する欲求 である. マズローは，(2)のような，他者の意見 を基に形成された自尊心が危険であることは過 去にも繰り返し示されていることを強調し, 自 尊心は, 実際に当人が持っている潜在能力や実 践的能力, あるいは仕事への適性に対する, (他 者からの）正当な尊重に基づくべきであるとし ている，その理由についてマズローの著書は, 過去の議論を参照するよう記しているのみだが,
正当な尊敬に基づく自尊心が内発的動機づけ16) と して成長欲求である自己実現の欲求へと結びっ いて行くのに対し，他者からの意見による自尊 心は外発的動機づけとして働き, 常により高い 評判や地位への欲求へとつながりやすく, 自己 実現の欲求につながりにくいためであろう.

自己実現の欲求を持つ人々は, 善や正義を追 求し, 社会全体の幸福を願う共同社会感情を持 つと言う.このような欲求を抱く個人が, 道徳 性の発達段階における第五段階, すなわち社会 契約的遵法主義を志向するであろうことは，想 像に難くない.

\section{5. 信頼の解き放ち理論}

直接的互恵にせよ, 間接的互恵にせよ, ある いは社会契約にせよ, ヒト, 所属する集団, あ るいは社会に対する信頼が, これらの行動には 必要となる. 山岸は, 質問紙調査と実験心理学 的研究を駆使して，ヒトのヒトに対する「信頼」 の構造を解き明かしている17) (図 2).

山岸は, 日本語の「信頼」とは, 「道徳的秩序 に対する期待」であるとしている ${ }^{1}$.これには, 相手の能力に対する期待と, 相手の意図（利己 的に振舞おうとするか, 利他的に振舞おうとす るか）に対する期待が含まれる，例えば，ある 医師の診療を受ける時, その医師の腕前に対す る信頼と, その医師が医師自身の利益を優先し, 患者である自分を金もうけの道具に利用したり はしないだろうという信頼の 2 種類の信頼があ るということである.

さらに, 相手の意図に対する期待は, 安心と (狭義の)信頼に分けられるという。ここで安心 とは，相手が利己的に振舞うことがその行為者 自身の不利になる状況を双方が認識しているた

1 英語のtrustには, 道徳的秩序に対する期待の他に，例 えば, 明日も太陽が東から昇るというような, 自然の秩 序に対する期待も含まれるそうである. 


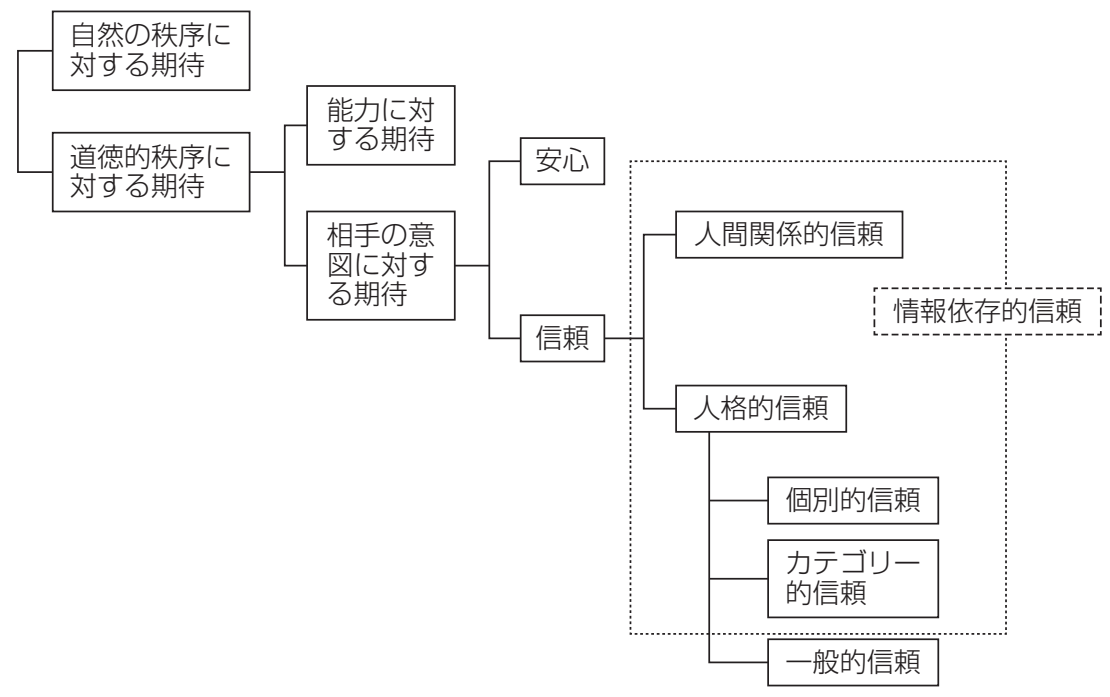

図 2. 信頼の構造

め，相手は利己的に振舞うことはないという確 信である. 例えば医師の診療を受ける場合, そ の医師の知り合いからの紹介で受診したり，医 師に正規の報酬以外の金品を渡したりした場合, もしその医師が不誠実な診療を行えば，医師は 知り合いとの関係に問題が生じたり, 正規の報 酬以外の金品を受け取ったことを公表されたり 返却を求められたりして結局は不利益を被る(罰 を受ける）ことになるから，不誠実な診療はし ないかも知れない. しかしこれは, その医師が 人格的に優れた人間であるからではないだろう.

(狭義の)信頼を, 山岸はさらに, 人間関係的 信頼と人格的信頼に分けている. 人間関係的信 頼とは, 相手の自分に対する好意の認識に基づ く信頼である. 人は, 好意を抱いている相手に 対しては通常, 利己的には振舞わないから, 相 手が自分に好意を抱いていると認識してれば, 相手を信頼することができるからである，そし て, 最後に残る人格的信頼は, 相手の人格が信 頼に值すると認識した場合に持つ信頼であり, 相手の表情や過去の行動などに関する情報に基 づいて, その相手が, 自分だけにではなく, 誰 に対しても分け隔てなく利他的に振舞うであろ
うと考える度合いである。そその意味で人格的信 頼の大きさは相手に関する情報に依存するが, それと同時に, 相手の人格を判断する側が, 初 期值として初対面の世間一般の人を信頼する度 合いによっても変化する. この人格的信頼の初 期值を, 山岸は一般的信頼と呼んでおり, これ は世間というもの全般への信頼と考えて良いも のと思われる。

確認だが, 人に対する信頼は, 相手の能力に 対する信頼, 安心, 人間関係的信頼, おょび人 格的信頼に分けられる，ここで，能力に対する 信頼は, 単独では不十分と言えるだろう。しか し, 安心, 人間関係的信頼, ないし人格的信頼 は, 理論上はいずれか一つでも十分に持てるな らば, 相手を信頼することができると思われる. 例えば, 手術が必要になった時, 仮にその手術 を行う技能が備わっているからと言って, 失敗 しても各められることがない立場にあり, 人間 関係が悪く, 人格的にも信頼できない外科医に 頼む気にはなれないだろう。しかし，失敗すれ ば必ず各められる立場にある外科医, あるいは, 自分を本当に大切に思ってくれている外科医, または，人格的に極めて信頼できる外科医なら 
表 1. 2種類のコミットメント関係

\begin{tabular}{|c|c|}
\hline $\begin{array}{l}\lceil\text { 相互利益に基づくコ } \\
\text { 三ットメン関係」 }\end{array}$ & $\begin{array}{l}\text { 「好意に基づくコミット } \\
\text { メント関係」 }\end{array}$ \\
\hline $\begin{array}{l}\text { ○「関係の効用」に期待 } \\
\text { する「付き合し」の関 } \\
\text { 係 } \\
\text { 排他的, 閉鎖的 } \\
\text { 自然こは解消しなし } \\
\text { 「忠誠」が求められる } \\
\text { 「裏切り」には社会的 } \\
\text { 制裁 }\end{array}$ & $\begin{array}{l}\text { 「関係の効用」を期待 } \\
\text { しない「友人」のよう } \\
\text { な関係 } \\
\text { 非排他的, 開放的 } \\
\text { 自然に解消することが } \\
\text { ある } \\
\text { 「誠実」が求められる } \\
\text { 内容により「守秘」が } \\
\text { 重要 }\end{array}$ \\
\hline
\end{tabular}

ば，自らにその手術を行う技能がないことがわ かっていて無謀な手術を行うことはないであろ うし，またその手術を自分の利益のために悪用 しようという意図はないと確信できるだろう. ただし，その外科医が実の親でもない限り，実 際に安心，人間関係的信頼，ないし人格的信頼 のいずれかのみで $100 \%$ 信頼することは難しい と思われるので, 医師は能力, 安心, 好意, 人 格の全ての面で信頼を得る努力が必要であろう.

山岸によれば，一般的信頼が低い人が用心深 さを持つと, 特定の相手や集団と, お互いに内 びいきを期待し，裏切れば村八分の制裁が加え られるという「安心」で結ばれた，そのために お互いに疑うことをせずに済む，言わば閉じら れた内向きのコミットメント関係を築きやすい (表 1).そこでは, 仲間であるかどうかが重視さ れ，集団内外の誰にでも正直に接する態度は軽 視されやすいのだと思われる。これは集団の内 部に限定された（直接的ないし間接的）互恵関 係と言って良いが，そのような関係は，集団の 外部からは排他的な集団として映ることになる.

一方, 一般的信頼が高い人では, 用心深さの レベルが低いと，特定の相手や集団と，お互い の好意で結ばれたコミットメント関係を築きや すい(表 1).ただしこの集団では, 仲間だから と言って集団外部の人間よりもひいきをしても らうことが当然だとは考えない。ささらに，一般
的信頼が高い人が用心深さを併せ持つと, 社会 に広く出て多くの人と出会い, しかしうまく利 用されることなく, 有益な取引き関係を持つこ とができるという。したがってこれは，広く社 会全体に開かれた（直接的あるいは間接的互恵） 関係であると言える.

山岸は，高い一般的信頼を持つことによって 限定的なコミットメント関係から広く社会に出 て活躍することが可能になるというこの現象を 指して,「信頼の解き放ち理論」と呼んでいる. ただしここで,「安心」で結ばれた閉鎖的なコミッ トメント関係の場合, 集団内部に限定された直 接的・間接的互恵関係から外れょうと試みるこ とに対して前述のように罰が与えられ，集団内 部での利他行動を強制される危険性がある点が 問題となる。一方, 純粋に好意に基づくコミッ トメント関係であれば，本来開放的な関係であ るので，そのような心配はないと思われる.

では，人が一般に人を容易に信頼せず，かつ， 用心深さを併せ持って, 仲間内に限定した互恵 関係を作るのは，どんな時が適しているのであ ろうか. また，人が人をまず信頼することから 始め, しかし用心深さも併せ持って, 広く社会 に出て, 多くの人と互恵関係を築くのは, どん な時が適しているのだろうか.

\section{6. 統治の倫理（武士道）と市場の倫理 (商人道)}

ジェイン・ジェイコブズは，世界中に伝わる 数々の倫理則を収集して分析し, 全ての倫理則 は, 次のような組合せの教訓を持つ, 二つの範 疇のいずれかに分類できることを明らかにし た ${ }^{18)}$ (表 2).

ジェイコブズによれば，人間が必要とするも のを入手するには, 縄張りから取得する (take) か，またはお互いに交換する（trade）かのいず れかである。縄張りを守るには戦わなければな 


\section{表 2. 統治の倫理と市場の倫理}

\begin{tabular}{l|l} 
取引を避けよ & 暴力を締め出せ \\
勇敢であれ & 自発的に合意せよ \\
規律遵守 & 正直たれ \\
伝統堅持 & 他人や外国人とも気安く協力 \\
位階尊重 & せよ \\
忠実たれ & 競争せよ \\
復讐せよ & 契約尊重 \\
目的のためには欺け & 創意工夫の発揮 \\
余暇を豊かに使え & 新奇·発明を取り入れよ \\
見栄を張れ & 効率を高めよ \\
気前よく施せ & 快適と便利さの向上 \\
排他的であれ & 目的のために異説を唱えよ \\
剛毅たれ & 生産的目的に投資せよ \\
運命甘受 & 勤勉なれ \\
名誉を尊べ & 節倹たれ \\
& 楽観せよ
\end{tabular}

らないし，交換をするためには平和に交流しな ければならない19). 前者は他の動物と同じ生活だ が, 後者は人間だけが行うものである. 人間の 生活にこの二つの様式があることに対応して, 人間の社会的道徳にも, 統治の倫理（上のリス トの左側）と市場の倫理（リストの右側）の二 つがある.両者はしばしば相互に矛盾・対立し, この二つの倫理を混同すると“救いがたい腐敗 が生ずる”のである.

西洋において, 市場の倫理に相当するものの 一つとして注目に值するのは, マックス・ウェー バーが指摘したプロテスタントの倫理 ${ }^{20)}$ であろ う. 従来のカトリックでは, 修道の場は修道院 にあり, 神の威光は教会の秩序によって示され ていたという。神への信仰を告白（profess）し て修道士以上の地位を得た者が, 神・法・医の 三学部で構成された当時の大学に入学が許され たため,これらの学部を修了して就く神官・法 曹・医師の 3 つだけが, 神の意思に基づく職業, すなわちプロフェッションと呼ばれることとなっ た.しかし, プロテスタントは教会の権威を否 定し, 信者の日々の生活の中に修道の場を求め たのである，信者にとって，全ての職業は神か
ら与えられた天職Berufであり, 懸命に自分の仕 事に打ち达み, 商売を発展させて社会全体に貢 献することこそが, 神への道だったのである.

さて，ジェイコブズが収集した倫理則には， 日本に伝わる倫理則も含まれていると言う。松 尾 ${ }^{21)}$ は, 我が国に伝わる武士道と商人道の特徵を 検討し, 武士道が統治の倫理に相当し, 商人道 が市場の倫理に相当すると指摘している. 日本 では, 江戸時代までは身分制度が存在し, 武士 は武士道, 商人は商人道と, それぞれの職に適 した倫理則に従って人生を送っていたという. 商人道とは, 石田梅岩によるいわゆる石門心学 や，近江商人の商家に伝わる家訓などである. 特に有名なのは, 近江商人に伝わる「売り手よ し, 買い手よし，世間よし」の精神である，戦 いとは勝者がいれば敗者がいるゼロサムゲーム (足してゼロになるの意味)であるが, 良い商売 とは, 売り手も買い手も, さらに世間も利を得 るものだという教えである．自分だけが得をし て相手に損をさせたり，自分と相手だけが得を して周り（世間）に損をさせるのは, 本当の商 売ではない.この考え方は, プロテスタンティ ズムが職業を通じた社会全体への貢献を目指し たことと良く似ている. また, 巷に言われる「情 けは人の為ならず」も，商売に限定せずに，同 じ意味を含んでいると思われる.

松尾は, 日本が明治維新を迎え, 全国民に薩 長土肥政権による武士道教育が行われ, さらに, 敗戦後の日本は武士道教育は放棄したものの, それに代わる倫理則として商人道を教えたわけ ではないため, 平和な経済国家としての倫理則 が成立していない中途半端な状態にあると指摘 している.

\section{7. プロフェッショナリズム再考〜社会契 約としての理解〜}

さて, 現代の我々日本人は, 他の国民と比較 
して,どのように人を信頼しているのだろうか. 山岸による米国人との比較では，次のことが明 らかとされている.

(1)日本人の一般的信頼はかなり低いレベルに ある（これは, 他の研究者による他の多くの 国の国民との比較でも同様である）

(2)日本人の用心深さは, 米国人と概ね同程度 である

(3)日本人は, 個人的な信頼関係と内ひいきを 区別していない

(4)日本人は，正直さを比較的軽視する

(5)日本人は，自分に対する周囲の評判を気に しやすい

6)日本人は, 人に対する信頼をその人の評判 で決める傾向は低い

このことから，日本人は「信頼」ではなく「安 心」で結ばれた，内向きの集団を形成しやすい ことがわかる.日本人におけるこれらの傾向は, 恐らく日本の医師にも当てはまるだろう。そし てその傾向は, 市場の倫理よりは統治の倫理と の親和性が高い.

しかしジェイコブズは, 臨床医というプロ フェッションを, 基本的に「市場の論理」が適 した職業として描いている，ただし，命を預か る医療のための道徳律として，特に「競争せよ」 の解釈には注意が必要だろう。これは, 医療を 拝金主義的な自由市場に任せれば良いというも のではない。資本主義の父とされるアダム・ス ミスが主張した自由市場は, 個々人が他者への 共感という道徳感情を持って取引きをすること を前提としていた ${ }^{22)} し$, 武士道と軍国主義が異な るように，商人道と帱金主義は異なるはずであ る. 大切なのは, ジェイコブズのリストの文言 に表面的に拘ることではなく，その奥にある，

2 医師に与えられるものは既にプロフェッション全体と 社会との間で約束されているのだから, 医師個人は日常 診療でその心配をする必要はない, という意味を込めて, 「医師よし」を最後としている。
開かれた誠実な互恵関係による社会全体の発展 への願いである。

さて, 社会契約とは,「基本的人権のような万 人が持つ不可侵の権利を互いに尊重することを 前提とした，社会全体の熟議に基づく互恵的な ルールの合意」であった。ここで考えなければ ならないのは，プロフェッショナリズムの文脈 でいうところの「社会契約」とは, 個々のプロ フェッショナルと社会との間に結ばれるのでは なく, プロフェッショナルの有機的集合体とし てのプロフェッションと, 国民の有機的集合体 としての社会との間の契約だということである. プロフェッションは, プロフェッショナルであ る医師一人ひとりの診療の質, 利他的な奉仕, 誠実さ・道徳心, 説明責任を, 社会に対して保 証する，社会は, 独占権 (免許), 自律権, 経済 的報酬, 名声をプロフェッションに対して約束 する.この時, プロフェッションという組織は, 一人ひとりのプロフェッショナルを「統治」す ることになるのだろうか.

そうではないと山岸は言う ${ }^{23)} .12 〜 13$ 世紀に 地中海貿易で活躍したジェノヴァ商人は，相手 を騙して商売をした者を裁く民事裁判所を多大 なコストをかけて設け，外国人でもそこに訴え 出ることができるようにすることで, ジェノヴァ 商人全体の信頼を維持したそうである.彼らは, 熟議と合意に基づいてそのシステムを作り，自 らの意志で参加したのである. 我々医師も, 数 ある職業の中でも社会の信頼の厚い医師という プロフェッションを選び，合意に基づいて参加 した(免許を受けた). 医師免許は, 高校や大学 での成績が良かった御褒美の延長ではなく，信 頼に基づく社会との,「患者よし, 社会よし, 医 師よし」2の医療とすることへの合意の証と考える べきなのではないだろうか.

謝辞 本稿で採り上げた進化倫理学をはじめとする様々な 理論について, 北海道大学大学院文学研究科の山岸俊男氏, 
立命館大学経済学部の松尾匡氏, 東京医科歯科大学名誉教授 の岡嶋道夫氏から多くの御教示を, 日本医学教育学会理事の 木下牧子氏には有益な御示唆を頂いた. また, 日本医学教育 学会倫理・プロフェッショナリズム委員会(後藤英司委員長) 委員諸氏, American College of Physicians Japan Chapterの Health and Public Policy Committee（大生定義委員長）委員 諸氏, 厚生労働科学研究費補助金地域医療基盤開発推進研究 事業「医療の質・安全を確保する新しい医療システムを実現 するための戦略に関する研究 (上原鳴夫主任)」研究班員 - 研 究協力者諸氏との有益な議論を通じて, 本稿の骨格が形成さ れた。ここに記して，深甚の謝意を表したい.

本研究は, 平成 20 年度 23 年度文部科学省科学研究費補 助金基盤研究 $(\mathrm{A})\lceil$ 「ともに考える医療”のための新たな患者一 医療者関係構築を目的とした実証・事業研究(尾藤誠司主任)」 の助成を受けて行われた.

著者のCOI (conflicts of interest) 開示 : 本論文発表内容に 関連して特に申告なし

\section{文献}

1）野村英樹 : プロフェッションによる教育と自律のあり方. 日内会誌 99 (5) : 1116-1121, 2010 .

2) 佐々木閑：仏教における「利他」の二つの概念. 科学 81 (1) : 66-67, 2011.

3）土井健司：隣人を無限に開く一キリスト教における隣人 愛の思想. 科学 81 (1) : 64-65, 2011.

4) Trivers RL: The Evolution of Reciprocal Altruism. Quarterly Rev Biol 46 : 35-57, 1971.

5) Nowak MA : Five Rules for the Evolution of Cooperation. Science 314 : 1560-1563, 2006.

6) Wilkinson GS : Reciprocal Food Sharing in the Vampire Bat. Nature 308 : 181-184, 1984.

7) 長谷川眞理子：利他の心の進化. 科学 81 (1) : 78-82, 2011.

8）大㭇 久：罰が怖いから協力する?一利他の起源と進化 シミュレーション. 科学 81 (1) : 76-77,2011.

9）ローレンス・コールバーグ, アン・ヒギンズ, 岩佐信道 : 道徳性の発達と道徳教育一コールバーグ理論の展開と実 践. 広池学園出版部, 1987.

10) Kohlberg L, et al : Moral Stages : A Current Formulation and a Response to Critics, Karger, Basel, NY, 1983(邦訳 : ローレンス・コールバーグ, アレクザンダー・ヒューアー, チャールズ・レバイン著, 片瀬一男, 高橋征仁翻訳. 道 徳性の発達段階 : コールバーグ理論をめぐる論争への回
答. 新曜社, 1992)

11) Self DJ, et al : The Moral Development of Medical Students : A Pilot Study of the Possible Influence of Medical Education. J Med Educ 27 : 26-34, 1993.

12) Patenaude J, et al : Changes in Students' Moral Development during Medical School: A Cohort Study. CMAJ 168: 840-844, 2003.

13) Sandel MJ:Justice:What's the Right Thing to Do? Farrar, Straus and Giroux, New York, 2009(邦訳 : マイケル・サ ンデル著, 鬼塚忍訳. これからの「正義」の話をしよう一 今を生き延びるための哲学. 早川書房, 東京, 2010)

14) Maslow AH : Motivation and Personality. $2^{\text {nd }}$ ed, Harper \& Row, New York, 1970(邦訳 : アブラハム・マズロー著, 小口忠彦訳. 人間性の心理学〜モチベーションとパーソ ナリティ. 産能大学出版部, 東京, 1987)

15) Goble FG:The Third Force:The Psychology of Abraham Maslow, Grossman Publishers, New York, 1970 (邦訳 : フランク・ゴーブル著, 小口忠彦監訳. 第三勢力〜マズ ローの心理学. 産能大学出版部. 東京, 1972)

16) Deci EL : Intrinsic Motivation, Extrinsic Reinforcement and Inequity. Journal of Personality and Social Psychology $22: 113-120,1972$.

17）山岸俊男 : 信頼の構造一こころと社会の進化ゲーム. 東 京大学出版会, 東京, 1998.

18) Jacobs J : Systems of Survival : A Dialogue on the Moral Foundations of Commerce and Politics, Hodder \& Stoughton, London, 1993 (邦訳 : ジェイン・ジェイコブ ズ. 市場の倫理・統治の倫理. 日本経済新聞社, 東京, 2003)

19) Ridley MW : The Origins of Virtue: Human Instincts and the Evolution of Cooperation, Penguin, London, 1996 (邦 訳 : マット・リドレー著, 古川奈々子訳. 徳の起源一他 人を拈もいやる遺伝子. 翔泳社, 東京, 2000)

20) Max Weber:Die Protestantische Ethik und der Geist des Kapitalismus, 1904 und 1905 (邦訳 : マックス・ヴェー バー著, 大塚久雄訳. プロテスタンティズムの倫理と資 本主義の精神．岩波書店，東京，1989）

21）松尾 匡：商人道ノス、メ. 藤原書店, 東京, 2009 .

22）堂目卓生：アダム・スミス一『道徳感情論』と『国富論』 の世界. 中央公論新社, 東京, 2008.

23）山岸俊男：日本医学教育学会倫理・プロフェッショナリ ズム委員会主催医学教育シンポジウム：『医のプロフェッ ショナリズムの新たなる展開〜互恵的利他主義に基づく 社会契約とは』における質疑応答. 東京, 2010 . 